\title{
Front Matter: Volume 11815
}

, "Front Matter: Volume 11815," Proc. SPIE 11815, Novel Optical Systems, Methods, and Applications XXIV, 1181501 (1 October 2021); doi:

10.1117/12.2606652

SPIE Event: SPIE Optical Engineering + Applications, 2021, San Diego, California, SPIE. United States 


\section{PROCEEDINGS OF SPIE}

\section{Novel Optical Systems, Methods, and Applications XXIV}

Cornelius F. Hahlweg

Joseph R. Mulley

Editors

1-5 August 2021

San Diego, California, United States

Sponsored and Published by

SPIE 
The papers in this volume were part of the technical conference cited on the cover and title page. Papers were selected and subject to review by the editors and conference program committee. Some conference presentations may not be available for publication. Additional papers and presentation recordings may be available online in the SPIE Digital Library at SPIEDigitalLibrary.org.

The papers reflect the work and thoughts of the authors and are published herein as submitted. The publisher is not responsible for the validity of the information or for any outcomes resulting from reliance thereon.

Please use the following format to cite material from these proceedings:

Author(s), "Title of Paper," in Novel Optical Systems, Methods, and Applications XXIV, edited by Cornelius F. Hahlweg, Joseph R. Mulley, Proc. of SPIE 11815, Seven-digit Article CID Number (DD/MM/YYYY); (DOI URL).

ISSN: 0277-786X

ISSN: 1996-756X (electronic)

ISBN: 9781510644687

ISBN: 9781510644694 (electronic)

Published by

SPIE

P.O. Box 10, Bellingham, Washington 98227-0010 USA

Telephone +1 3606763290 (Pacific Time)

SPIE.org

Copyright @ 2021 Society of Photo-Optical Instrumentation Engineers (SPIE).

Copying of material in this book for internal or personal use, or for the internal or personal use of specific clients, beyond the fair use provisions granted by the U.S. Copyright Law is authorized by SPIE subject to payment of fees. To obtain permission to use and share articles in this volume, visit Copyright Clearance Center at copyright.com. Other copying for republication, resale, advertising or promotion, or any form of systematic or multiple reproduction of any material in this book is prohibited except with permission in writing from the publisher.

Printed in the United States of America by Curran Associates, Inc., under license from SPIE.

Publication of record for individual papers is online in the SPIE Digital Library.

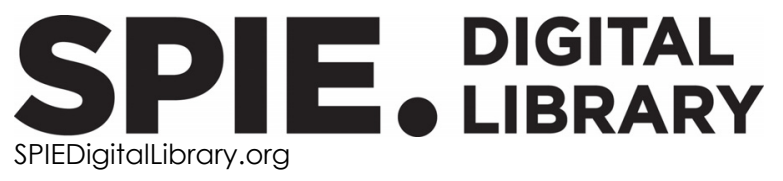

Paper Numbering: A unique citation identifier (CID) number is assigned to each article in the Proceedings of SPIE at the time of publication. Utilization of CIDs allows articles to be fully citable as soon as they are published online, and connects the same identifier to all online and print versions of the publication. SPIE uses a seven-digit CID article numbering system structured as follows:

- The first five digits correspond to the SPIE volume number.

- The last two digits indicate publication order within the volume using a Base 36 numbering system employing both numerals and letters. These two-number sets start with $00,01,02,03,04$, 05, 06, 07, 08, 09, 0A, OB ... 0Z, followed by 10-1Z, 20-2Z, etc. The CID Number appears on each page of the manuscript. 


\section{Contents}

BIOMEDICALAPPUCATIONS AND HUMAN PERCEPION

1181502 Remote measurement of sphero-cylindrical lens power and orientation through distortion analysis (Invited Paper) [11815-3]

1181503 Visualization of the optoacoustic effect of ultrashort laser pulse using finite element method [11815-1]

$1181504 \quad$ Holographic combiners for augmented reality applications fabric ated by wave front recording [11815-5]

HYPERSPEC TRALAND RUORESCENCE APPUCATIONS

$1181505 \quad$ Multi-excitation fluorescence imaging for identifying clanity enhancement in gemstones [11815-6]

1181506 Hyperspectral characterisation of natural illumination in woodland and forestenvironments [11815-7]

MATERIALS AND MANUFACTURING

1181509 Wavelength- and angle-resolved technique for detemining the energy-momentum diagram of photonic systems [11815-9]

11815 OA Industrial processing for printed polymeroptical waveguides [11815-10]

11815 OB Fabrication of an integrated optical system in glass using laser assisted manufacturing (Invited Paper) [11815-12]

11815 OC Material removal mechanism of single crystal silic on by bonnet polishing [11815-14]

MODEUNG AND COMPUTATIONALMETHODS

11815 OD Optimal design of aspheric acoustic lens based on ray tracing [11815-15]

$11815 \mathrm{OE} \quad$ On the use-case-specific quality degradations of light field visualization [11815-16] 
11815 OF SPAD-based time-of-flight disc rete-time statistical model and distortion compensation [11815-19]

11815 OG Point source localization with a planar optical phased anay compressive sensor [11815-20]

$11815 \mathrm{OH} \quad$ Comparison of diagonal double weight and multi-diagonal codes for sec unity enhancement in PONs [11815-21]

11815 ol Advances in Raman-based broadband optical refrigeration [11815-22]

\section{POSTER SESSION}

11815 OK Design and implementation of 3D scene walkthrough system based on augmented reality [11815-4]

$11815 \mathrm{OL}$ Visualization of the relationship between photothermal effectand wavelength in gastric tumor based on finite element analysis [11815-24]

11815 OM Recognition of gastric tumor using photon tracing based on Monte Carlo method [11815-25]

11815 ON Fast high-quality sparse reconstruction of photoacoustic imaging based on HIP compressed sensing [11815-26]

1181500 Camouflage pattem segmentation for calculation of apparent reflectance spectra [11815-27]

$118150 Q$ Hands-on project aimed at technical education: realizing a DC magnetron sputtering system [11815-29]

$118150 \mathrm{~T}$ Schlieren technique to visualize the temperature gradient around an optical fiber tip [11815-32]

11815 OU Heart signals sensor based on optical fiber Fabry-Perot interferometer [11815-33]

11815 OV Fuorescence microscope as a core instrument for extratemestrial life detection methods [11815-34]

11815 OW Freeform optical elements usage in imaging optical systems design [11815-35]

11815 oY Eccentric fixation measurements using visuosc opy and Macula Integrity Tester (MIT) in children with amblyopia [11815-37]

1181510 Development of the optical sc heme and design of a solar sculptural composition for installation on a city street [11815-39] 